https://doi.org/10.31470/2706-7904-2020-15-116-121

\title{
ПРОЯВИ ОСОБИСТІСНИХ СМИСЛІВ У МОВЛЕННЄВІЙ КОМУНІКАЦІї ПІДЛІТКІВ
}

\section{Manifestations of personal meanings in Speech Communication of Adolescents}

\author{
Tetiana Kyrychenko \\ Ph.D. in Psychology, Assistant Professor \\ Pereiaslav-Khmelnytskyi Hryhorii Skovoroda State Pedagogical University (Ukraine) \\ glushenko13@ukr.net \\ https://orcid.org/0000-0002-6845-0628
}

\begin{abstract}
According to the results of the study, it is pointed out that individual personality traits are manifested in the speech expression as a product of speech activity in the following characteristics: (1) proper linguistic (linguistic, speech and semantic); (2) psychological (motivational, cognitive, emotional, productive and resultative). The scientific and categorical analysis of the understanding the concept of personal meaning and the factors influencing its formation has been made. The article considers interpersonal speech communication of adolescents as a semantic interaction of its subjects, which involves the presence of such speech abilities as speaking and listening, the functional communicative unit of which is the statement (message) that is inextricably linked with the lexical-semantic and grammatical meanings.
\end{abstract}

Key words: speech activity, linguistic personality, dialogic speech, interpersonal speech communication, meaning, story.

\section{Вступ \\ Introduction}

Проблема особистісного смислу в онтогенезі мовлення людини - одна із найбільш фундаментальних у психології мовлення і психолінгвістиці. Особлива увага дослідників (Выготський, 2001; Леонтьев, 1983; Леонтьев, 2003; Калмикова, 2016) сконцентрована на вивченні смислового сприйняття мовленнєвого висловлювання, а також його породженні і розумінні. У дослідженнях мовленнєвого онтогенезу перспектива наукових розвідок в означеному напрямі, пов'язана з усвідомленням того, що усні висловлювання не можуть бути зрозумілими та осмисленими без 
приналежності до оточуючої дійсності, різних життєвих ситуацій, міжособистісної комунікативно-мовленнєвої взаємодії (Зачёсова, 2007; Ушакова, 2008; Tomasello, 2008; Bruner, 2004). Незважаючи на існуючі дослідження в цій галузі, проблема визначення проявів особистісних смислів у мовленнєвих висловлюваннях підлітків залишається до цього часу недостатньо вивченою.

\section{Методи та методики дослідження}

\section{Methods and Techniques of the Research}

Для досягнення мети та вирішення поставлених завдань було використано такі методи: ретроспективний аналіз психологічної й психолінгвістичної літератури, узагальнення результатів аналізу наукових положень, синтез, співставлення i порівняння визначених підходів щодо розуміння особистісного смислу у мовленнєвій діяльності підлітків за їх істотними ознаками.

\section{Результати}

\section{Results}

Відомо, що особистість формується і проявляється у діяльності, в тому числі мовленнєвій діяльності, яка визначається єдністю двох сторін - зовнішньої, що реалізує саму діяльність, і внутрішньої, що здійснює іiі організацію, планування i програмування. Вивчення проявів особистості в мовленнєвій діяльності - це і є шлях до розуміння ii смислів. Мовленнєву комунікацію розглядаємо як необхідну взаємодію двох або більшої кількості ії суб'єктів, що визначається не тільки як передача інформації й не зводиться до поняття спілкування; це є спеціалізоване використання мовлення для психосоціальної смислової взаємодії.

Результати теоретичного аналізу означеної проблеми у наукових джерелах свідчать про такі основні підходи до розуміння категорії «особистісний смисл»:

(1). Особистісний смисл аргументується у вітчизняній психології в контексті взаємозв’язку 3 поняттям «значення». Ще Л.С. Виготський (Выготский, 2001) пов'язував розвиток осмисленого сприймання із значенням слова. Згідно поглядів видатного психолога, важливою умовою розвитку особистісного смислу є набуття індивідом спроможності розуміння усного висловлювання через оволодіння системою мовних значень, що «стоять» за одиницями мови, зокрема словом.

(2). Розгляд особистісного смислу як складового компоненту свідомості, де інтегровано такі поняття: (а) чуттєві образи; (б) значення; (в) особистісний смисл; представлений в межах діяльнісного підходу О.М. Леонтьєвим (Леонтьев, 1983). 
Особлива функція чуттєвих образів полягає в тому, що вони надають відчуття реальності свідомій картині світу суб'єкта. Особистісний смисл вчений визначає як індивідуалізоване відображення справжнього ставлення особистості до тих об'єктів, заради яких розгортається їі діяльність й усвідомлюється як «значення для мене».

(3). Розмежування значення та особистісного смислу містяться в дослідженнях суб’єктивної семантики. Зокрема, О.Ю. Артемьєва (Артемьева, 1999) зробила спробу визначити схожість і відмінність цих категорій, що дає підстави для диференціації логічного й психологічного їх структурування. Так, дослідницею зазначено, що особливості їх психологічного розмежування грунтуються на різних підходах конструювання психологічного значення, які варіюють від індивіда до індивіда внаслідок різного змісту їх концептуальних систем. О.Ю. Артемьєва звертає увагу на «конфлікт особистісних смислів», зазначаючи, якщо конфлікту немає, то особистісний смисл підтверджується, але не відбувається його трансформація.

(4). Виокремлення трьох головних аспектів особистісного смислу, містяться в роботі Д.О. Леонтьєва (Леонтьев, 2003) «Психологія смислу. Природа, будова і динаміка смислової реальності», а саме: (1) генетичний; (2) функціональний; (3) структурний. 3 точки зору науковця, в генетичному аспекті смисл породжується мотивом. У функціональному аспекті смисл виконує роль «мотиваційно-смислового орієнтування», а у структурному аспекті смисли похідні від реальних життєвих відносин. При цьому зазначається, що структурний аспект включає в себе уявлення про місце особистісного смислу в структурі діяльності й свідомості суб'єкта. Згідно уявлень автора, це $є$ сполучна ланка між свідомістю і діяльністю, крім того, по відношенню до діяльності смисл виступає як іiі продукт, в той час, як в контексті аналізу свідомості смисл постає як суттєвий iї конщеnт. У зв'язку з цим смисл, наголошує вчений, характеризує не діяльність, а особистість, як систему особистісних смислів. Д.О. Леонтьєв виділяє такі смислові структури: особистісний смисл, смислова установка, мотив, смислова диспозиція, смисловий конструкт та ін. Суттєво значущим $є$ те, що до структури особистості вчений не відносить особистісний смисл, смислову установку та мотив, тому що вони можуть змінюватися всупереч смисловим конструктам, смисловим диспозиціям та цінностям, які мають «наддіяльнісний» характер (Леонтьев, 2003: 129). Учений підкреслює нетотожність особистісного й життєвого смислу, характеризуючи життєвий смисл як об'єктивну характеристику відношення об’єктів і явищ дійсності до життєдіяльності суб'єкта, а особистісний смисл як форму суб' єктивного відбиття цього відношення в свідомості суб'єкта, в його образі світу (Леонтьев, 2003: 168).

(5). Положення щодо розуміння особистісного смислу з точки зору філософії. Так зокрема, Г.П. Щедровицьким (Щедровицкий, 1995) смисл визначається як 
співвідношення та зв'язок всіх явищ, які дотичні до ситуації й розкривають його соціальні та особистісні форми.

(6). Особистісний смисл у трактуванні М.М. Бахтіна (Бахтин, 2003) означає, особистісне ставлення до власної діяльності, до мети, до засобів, до стимулів і перепон. Важливим показником знання про смислові взаємозв'язки між елементами діяльності, що «задає особливу дійсність діяльності», вважає науковець, є досвід індивіда набутий через виховання й навчання. Оскільки, в своїх уподобаннях при осмислені необхідних дій та операцій людина об’єктивно обмежена досвідом, то іiі діяльність відображає сочіальні еталони разом із особистісними смисловими взаємозв' язками.

Отже, на основі аналізу наукових джерел 3 проблем природи смислу, смислоутворення доведено, що поняття «особистісний смисл» репрезентує уявлений образ сутності (змісту) будь-якої події, явища, що є життєвозначущим і результативним для особистості у зв’язку з необхідністю задоволення ії інтересів та потреб.

Із вищевикладеного випливає, що підліток набуває особистісний смисл пізнаючи, чи переживаючи різноманітну інформацію, життєві ситуації, сукупність обставин, роздуми про пережите. Слід зауважити, що надзвичайно важливою умовою розвитку мовної особистості $\epsilon$ набуття спроможності розуміння усного висловлювання через утворення особистісного смислу, що передбачає наявності мовленнєвого середовища з високим розвивальним потенціалом (Калмикова, 2016).

Описані вище підходи звертають до аналізу інтерпретації особистісного смислу в розповідях підлітків. Інтерпретація особистісних смислів у мовленнєвих висловлюваннях створює наративи, які в свою чергу, дозволяють фіксувати особистісний смисл індивіда в семантичних одиницях мовлення. Необхідно зазначити, що у висловлюванні мовцем, своєрідним чином реалізується особлива внутрішня потреба розуміння прихованих мотивів, намірів іншим комунікатором, осмислено сприймаючи інформацію.

М. Томаселло (Tomasello, 2008) зазначає, що мотив або бажання індивіда поділитися «своїм світом» (відчуттями, поглядами) є способом інформування. Подібне прагнення індивіда поділитися 3 іншими своєю інформацією, враженнями про події дозволяє мовцю знайти і розширити «щось спільне», що об'єднує його 3 іншими, влитися в групу і бути прийнятим нею. 3 іншого боку, за допомогою висловлювання відбувається осмислення індивідом простих i більш складних фрагментів його досвіду, в яких представлені процеси виділення й оцінки різних подій, а також розкриваються внутрішні причини його поведінки і дій (Bruner, 2004).

Однією з умов, що впливає на формування особистісного смислу є діалогічне мовлення. Проблема діалогу - центральна в психолінгвістичних дослідженнях. 
Т.А. Флоренська (2001) наголошує, що життя людини - це діалог між «наявним Я» та «духовним Я» й трактує діалог як вищий духовно-особистісний рівень людського спілкування.

Натомість, Т.М. Ушакова (Ушакова, 2008) вважає одним із найбільш пріоритетних напрямків дослідження проявів особистісних смислів - описання інтенціонального підтексту міжособистісної комунікативної взаємодії, що визначається значенням інтенцій у мовленні та мовленнєвому спілкуванні. Інтенції утворюють основу й глибинний психологічний зміст мовлення, яке безпосередньо пов'язане 3 цілями діяльності і баченням світу суб'єктом, його бажаннями, потребами, установками.

Відтак, згідно 3 сучасними уявленнями науковців, висловлювання не обмежується вираженням судження. За І.О. Зачесовою (Зачёсова, 2007), основу і його психологічний зміст утворюють інтенції (наміри). Дослідження інтенціональної організації висловлювання показали, що вираження i розпізнавання інтенцій $\epsilon$ важливою складовою мовленнєвої міжособистісної взаємодії. Передача інтенцій $є$ необхідною основою взаєморозуміння, координації дій, досягнення мети мовців. Від характеру інтенцій залежить смисл сказаного, розуміння в процесі діалогу. Крім того, важливу роль у формуванні особистості відіграє розуміння іншими внутрішнього світу, суб'єктивної спрямованості іiі свідомості, вираженої в інтенціональному підтексті діалогу. Ідентичність «Я» формується при зустрічі різних думок. Вербальна взаємодія з іншими поступово стає спілкуванням з собою і для себе.

Таким чином, формування смислів у внутрішньому мовленні комунікантівслухачів (реципієнтів) на підставі сприйнятої інформації засвідчує не тільки іiі контекстне розуміння, а й розуміння глибинних мовленнєвих інтенцій і прихованих мотивів, які спричиняли перебіг процесу говоріння мовця.

\section{Висновки \\ Conclusions}

Отже, системне узагальнення уявлень науковців щодо сутності особистісного смислу свідчать, що на сьогодні не виявлено загального підходу як до визначення змістовних характеристик особистісного смислу, так і до його складових концептів, що $\epsilon$ проблемою при аналізі особливостей прояву особистісного смислу у мовленнєвих висловлюваннях підлітків. Відтак, набуває особливої значущості віднайдення такої описової одиниці, яка могла б виявити природу особистісного смислу в онтогенезі мовлення. 3 огляду на вищезазначене такою описовою одиницею, в контексті означеної теми, може виступати концепт суб’єкта комунікативно- 
мовленнєвої діяльності, який існує в ментальному просторі людини не у вигляді чітких понять, а як система уявлень, знань, асоціацій, переживань, які супроводжують слово.

\section{Література \\ References}

Артемьева, Е.Ю. (1999). Основы психологии субъективной семантики. Москва: Смысл.

Бахтин, М.М. (2003). К философии поступка. (В 7 т.). (Т. 1, с. 7-68). Москва: Русские словари.

Выготский, Л.С. (2001). Мышиление и речь. Москва: Лабиринт.

Зачесова, И.А. (2007). Интенциональная организация семейного бытового дискурса и взаимоотношения собеседников. Языковое сознание: парадигмы исследования (с. 297317). Москва - Калуга: Эйдос.

Калмикова Л.О. (2016). Про стан розвитку мовлення як діяльності у дітей п'яти років. Psycholinguistics, 19(1), 84-97.

Леонтьев, А.Н. (1983). Избранные психологические произведения. (В 2-х т.). (Т.1). Москва: Педагогика.

Леонтьев, Д.А. (2003). Психология смысла. Природа, строение и динамика смысловой реальности. (2-е изд.). Москва: Смысл.

Ушакова, Т.Н. (2008). Узловые проблемы раннего речеязыкового развития ребенка. Т.Н. Ушакова (Ред.), Речь ребенка: проблемы и решения (с. 13-19). Москва: Изд-во «Институт психологии РАН».

Флоренська, Т.А. (2001). Диалог в практической психологи: наука о душе. Москва: ВЛАДОС.

Щедровицкий, Г.П.(1995). Избранные труды. Москва: Изд-во «Школы культурной политики».

Bruner, J.S. (2004). Life as narrative. Social research, 71(3), 691-710.

Tomasello, M. (2008). Origins of human communication. Cambridge, MIT, London. https://doi.org/10.7551/mitpress/7551.001.0001 